\title{
Peran Intellectual Capital Terhadap Organizational Value
}

\author{
Dodi Siswanto \\ Siswantododi88@gmail.com \\ Program Studi Manajemen, Fakultas Ekonomi, Universitas Al-Ghifari
}

\begin{abstract}
ABSTRAK
The discussion related to Intellectual Capital becomes a very interesting matter for organizations, this is because intellectual capital is an invisible asset that can have an extraordinary impact, can provide added value to the company so as to increase organizational competitiveness. Therefore, business owners (MSMEs) need to be aware of this. The purpose of this research is to examine how strategies to strengthen intellectual capital in increasing the organizational value of MSMEs. The dimensions studied in this study are Human Capital, Capital Structure, Customer Capital, and Social Capital. This type of research uses qualitative methods with a literature study approach. This human capital formation can be done through employee self-development by providing education and training. Learning about culture, infrastructure, and the right incentives to generate and disseminate knowledge are ways to strengthen the Capital Structure. Providing excellent service is an effort to retain customers. Bonding Social Capital, Bridging Social Capital, Linking Social Capital are social capital that can provide a conceptual understanding that social capital that is formed can create different results.

Keywords: Intellectual capital, organizational values.
\end{abstract}

\section{Latar Belakang}

Intellectual Capital merupakan asset yang harus dimiliki oleh organisasi peusahaan agar dapat terus bersaing. Para pelaku bisnis menyadari bahwa untuk meraih kesuksesan bukan hanya mengandalkan aktiva berwujud saja, tetapi peran aktiva tak berwujud dalam hal ini intellectual capital memegang peranan yang tak kalah penting dalam mencapai keberhasilan. Menurut Kuryanto dalam (Santoso, 2011) Modal Intelektual belum dikenal secara luas di Indonesia. Sampai dengan saat ini perusahaan-perusahaan di Indonesia cenderung menggunakan conventional based dalam membangun bisnisnya sehingga produk yang dihasilkan masih miskin teknologi. 
Disamping itu perusahaan-perusahaan tersebut belum memberikan perhatian lebih terhadap human capital, structure capital, dan customer capital, padahal semua itu merupakan pembangun modal intellectual perusahaan. Pentingnya modal intelektual ini memaksa perusahaan untuk meningkatkan modal intelektual kapital yang dimilikinya.

Intelektual merupakan asset yang dimiliki oleh perusahaan harus mampu dikelola dengan baik sehingga mampu memberikan nilai tambah, keberhasilan dalam pengelolaan modal intelektual dapat memberikan nilai tambah yang unik dan sulit untuk ditiru oleh kompetitor. Perusahaan yang memiliki Intellectual capital yang baik dapat tercermin dari kompetensi dan komitmen dari anggota organisasinya. Untuk itu perusahaan harus berusaha untuk meningkatkan kompetensi dan komitmen dari anggota organisasi atau pegawainya. Masih menurut Kuryanto dalam (Santoso, 2011) perusahaanperusahaan di Indonesia akan dapat bersaing apabila menggunakan keunggulan kompetitif yang diperoleh melalui inovasi-inovasi kreatif yang dihasilkan oleh modal intelektual perusahaan. Hal ini mendorong terciptannya produk-produk yang semakin favourable dimata konsumen.

UMKM mempunyai peran yang strategis dalam pembangunan ekonomi nasional, selain berperan dalam pertumbuhan ekonomi dan penyerapan tenaga kerja juga berperan dalam pendistribusian hasil-hasil pembangunan. Peningkatan pembangunan ekonomi untuk meningkatkan daya saing UMKM tergantung pada keefektifan pengelolaan pengetahuan dan teknologi, ilmu pengetahuan dan teknologi diciptakan dari knowledge perorangan yang harus dikelola agar menjadi knowledge perusahaan yang akhirnya menjadi asset tak berwujud yang dimiliki oleh UMKM (Zuliyati \& Delima, 2017). Lebih lanjut (Cyntya\&Setiawan, 2013) pada era informasi, kunci kesuksesan suatu perusahaan tidak lagi ditentukan oleh sumber daya fisik yang dimiliki perusahaan, sumber daya non fisik yang kini menjadi indicator yang dominan di dalam keberhasilan suatu perusahaan. sumber daya non fisik atau asset intangible, terutama pengetahuan dan informasi menjadi semakin penting di dalam dunia bisnis dan ekonomi sekarang ini. Dengan kata lain dapat dikatakan juga bahwa pada saat ini dunia telah dilanda oleh era pengetahuan (knowledge). Intinya Intelektual Kapital merupakan jawaban dari era informasi dan pengetahuan tersebut. 
Melihat kondisi saat ini, UMKM yang ada di Indonesia sepertinya masih banyak yang belum menyadari pentingnya bisnis berbasis pengetahuan dengan mengoptimalkan intelektual capital yang dimilikinya, sebagaimana diketahui bahwa UMKM merupakan sector industry yang memberikan kontribusi besar terhadap PDB di Indonesia yang diharapkan eksistensinya mampu dalam menopang perekonomian, modal intelektual ini merupakan salah satu sumber daya tidak terlihat tetapi memberikan dampak yang signifikan terhadap peningkatn nilai dan keuntungan perusahaan (Widiastuti \& Sulistyandari, 2013).

Kebanyakan UMKM saat ini dalam usahanya hanya berfokus terhadap permasalahan modal pendanaan saja, mereka belum memahami bahwa intelektual capital memberikan kontribusi terhadapa usahanya. Menurut Artati dalam (Salsabila, 2019) Perusahaan dalam era ekonomi modern saat ini, Intektual Kapital menjadi asset yang sangat penting apabila dibandingkan dengan asset fisik. Hal ini menunjukan bahwa pada era modern seperti ini modal secara fisik atau pendanaan tidaklah cukup untuk mengelola bisnis mencapai kinerja sesuai yang diharapkan. Lebih lanjut menurut Alhabschic dalam (Salsabila, 2019) komponen Intelektual Kapital terdiri dari Human Capital, Structure Capital, Customer Capital, Socia Capital, Technological Capital, dan Spiritual Capital.

Nilai organisasi merupakan tuntunan atau pedoman yang mendasari bagaimana sesorang atau sebuah organisasi berfikir, mengambil keputusan, bersikap dan bertindak, nilai-nilai juga bisa diartikan gambaran dialog yang selalu terjadi dalam diri kita, yang menentukan apa yang penting apa yang penting dan apa yang tidak, apa yang dan apa yang tidak (Hapsari, 2015). Organisasi yang baik memerlukan penerapan nilai-nilai yang baik pula terutama agar dapat menjalankan misi dengan lancar sehingga tercapai visi yang diharapkan. Dari latar belakang tersebut sangat menarik untuk melakukan pengkajian lebih lanjut terkait bagaimana intelektual capital dapat meningkatan nilai organisai pada UMKM.

\section{Kajian Literatur}

Kewirausahaan

Kewirausahaan merupakan merupakan proses penerapan kreatuvitas dan inovasi untuk memecahkan masalah dan mencari peluang yang dihadapi 
setiap orang dalam kehidupan sehari-hari, inti dari kewirausahaan adalah kemampuan untuk menciptakan sesuatu yang baru dan berbeda melalui pemikiran kreatif dan tindakan inovatif demi terciptanya peluang, Thomas W. Zimerer (Saragih, 2017), lebih lanjut Hisrich dalam (Dzulfikri \& Kusworo, 2019) menjelaskan bahwa kewirausahaan adalah proses penciptaan sesuatu yang baru pada nilai menggunakan waktu dan upaya yang diperlukan, menanggung resiko keuangan, fisik, serta resiko social yang mengiringi, menerima moneter yang dihasilkan, serta kepuasan dan kebebasan pribadi.

Sedangkan menurut (Suharyono, 2014) kewirausahaan adalah usaha untuk menciptakan nilai tambah dengan jalan mengkombinasikan semua sumber daya ekonomi melalui cara-cara baru dan berbeda untuk memenangkan persaingan. Dapat diartikan bahwa inti dari kewirausahaan adalah sebagai berikut :

a. Kemampuan untuk menciptakan sesuatu yang baru (create new and defferent) melalui berikir kreatif dan bertindak inovatif untuk menciptakan peluang dalam menghadapi tantangan hidup.

b. Merupakan sifat, ciri dan watak seseorang yang memiliki kemauan dalam mewujudkan gagasan inovatif ke dalam dunia nyata secara kreatif.

c. Proses kewirausahaan meliputi semua kegiatan fungsi dan tindakan untuk mengejar dan memanfaatkan peluang dengan menciptakan suatu organisasi.

\section{UMKM}

Menurut Azrin dalam (Hafni \& Rozali, 2017) Usaha Mikro Kecil dan Menengah (UMKM) merupakan stimulant perekonomian pada negara berkembang dan memiliki keunggulan apabila dibandingkan dengan usaha besar, antara lain :

1. Inovasi dalam teknologi yang telah dengan mudah terjadi dalam pengembangan produk.

2. Berbasis pada sumber daya local sehingga dapat memanfaatkan potensi secara maksimal dan memperkuat kemandirian.

3. Kemampuan menciptakan lapangan kerja cukup banyak atau penyerapan tenaga kerja. 
4. Fleksibilitas dan kemampuan menyesuaikan diri terhadap kondisi pasar dengan cepat dibandingkan dengan perusahaan dalam skala besar yang pada umumnya birokratis.

5. Terdapat dinamisme manajerial dan peran kewirausahaan.

6. Dimiliki dan dilaksanakan oleh masyarakat local sehingga mampu mengembangkan sumber daya manusia.

7. Tersebar dalam jumlah yang sehingga merupakan alat pemerataan pembangunan yang efektif.

Sedangkan masalah dasar yang sering dialami oleh Usaha Mikro Kecil dan Menengah (UMKM) :

1. Kelemahan dalam memperoleh peluang pasar dan memperbesar pangsa pasar.

2. Kelemahan dalam struktur permodalan dan keterbatasan untuk memperoleh jalur terhadap sumber-sumber permodalan.

3. Kelemahan dibidang organisasi dan manajemen sumber daya manusia.

4. Keterbatasan jaringan usaha kerjasama antar pengusaha kecil ( system informasi pemasaran)

5. Iklim usaha yang kurang kondusif karena persaingan yang saling mematikan.

6. Pembinaan yang telah dilakukan masih kurang terpadu dan kurangnya kepercayaan serta kepedulian masyarakat terhadap usaha kecil.

\section{Intelektual capital}

Dewasa ini pemahaman terkait Intelektual capital perlu dimiliki oleh setiap perusahaan, Intelektual kapital merupakan asset tak berwujud, dengan memahami pentingnya asset tersebut perusahaan dapat menyusun dan menetapkan strategi serta kebijakan-kebijakan untuk mengevaluasi dan memaksimalkan produktivitas asset yang dimiliki. Intelektual capital dipandang sebagai sumber daya yang menciptakan nilai dan memastikan keunggulan kompetitif bagi organisasi, intinya intelektual capital merupakan semua tentang apa yang perusahaan harus lakukan jika perusahaan menginginkan kemenangan (Astuti, 2015). 
Untuk lebih memahami intelektual capital beberapa definisi dijelaskan sebagai berikut, menurut (Narimawati, 2011) Modal Intelektual atau Intellectual Capital merupakan harta tak terlihat yang dimiliki oleh organisasi perusahaan yang dapat digunakan untuk menciptakan nilai bagi organisasi perusahaan melalui perpaduan antara human capital (modal manusia), Struktur capital (modal struktural), dan Customer capital (modal pelanggan). Kombinasi dari ketiga unsur tersebut merupakan merupakan asset yang dapat menciptakan value added pada organisasi perusahaan. Intellectual Capital dapat membawa dampak yang sangat penting dan strategi bagi organisasi perusahaan. Modal intelektual tidak hanya sebatas goodwill atau patent saja yang sering dilaporkan dalam laporan keuangan neraca suatu perusahaan, tetapi lebih dari itu, kompetensi yang dimiliki oleh pegawai, hubungan dengan pelanggan, penciptaan inovasi, merupakan bagian dari modal intelektual. Selanjutnya Nahapit dan Gosal dalam (Santoso, 2011) menjelaskan Intelektual capital adalah pengetahuan dan kemampuan yang dimiliki oleh suatu koletivitas sosial, seperti organisasi, komunitas intelektual, atau praktek professional. Modal intelektual mewakili sumberdaya yang bernilai dan kemampuan untuk bertindak yang didasarkan pada pengetahuan. Modal intelektual ini adalah pengetahuan (knowledge), tetapi tidak semua pengetahuan termasuk modal intelektual. Modal intelektual merupakan bagian pengetahuan yang dapat memberikan manfaat bagi perusahaan sehingga dapat memberikan nilai tambah bagi perusahaan. Modal intelektual seperti yang telah dijelaskan sebelumnya terbagi kedalam tiga sumber yaitu :

1. Kompetensi karyawan, yaitu segala kemampuan, keahlian, keterampilan, pengetahuan dan performa bisnis yang dimiliki oleh karyawan (human capital)

2. Struktur internal organisasi yaitu kemampuan, keahlian, keterampilan, pengetahuan, dan performa bisnis yang dimiliki oleh perusahaan.

Hubungan eksternal/pasar antara lain dengan konsumen, supplier dan pemerintah (Customer capital). Sedangkan Klein dan Prusak dalam (Cyntya\&Setiawan, 2013) modal intelektual adalah materi intelektual yang telah diformalisasikan, ditangkap, dan dimanfaatkan untuk memproduksi asset yang nilainya lebih tinggi. Setiap organisasi menempatkan materi 
intelektual dalam bentuk asset dan sumber daya, perspektif, kemampuan eksplisit, dan informasi, pengetahuan, dan mungkin kebijakan. Lebih lanjut Bontis (Hartati, 2015) mengemukakan intelektual capital adalah seluruh kemampuan pekerja yang menciptakan tambahan nilai.

\section{Human Capital}

Garis besar pengertian human capital adalah kemempuan yang ada di dalam diri seseorang, dapat dinyatakan dari yang terlihat maupun yang masih terpendam, kemampuan seseorang yang terlihat dapat tercermin dari penyelesaian pekerjaan sehari-hari dengan penilaian terkini atas apa yang dapat dilakukan oleh seseorang di dalam organisasi, dengan kata lain yaitu kapasaitas seorang individu untuk melakukan beragam tugas dalam suatu pekerjaan organisasi (Prasojo, 2017). Menurut Schermerhon dalam (Endri, 2010) human capital dapat diartikan sebagai nilai ekonomi dari SDM yang terkait dengan kemampuan, pengetahuan, ide-ide, inovasi, energy dan komitmen. Human capital merupakan kombinasi dari pengetahuan, keterampilan, inovasi dan kemampuan seseorang untuk menjalankan tugasnya sehingga dapat menciptakan suatu nilai untuk mencapai tujuan.

Selanjutnya Davenport (Salsabila, 2019) human capital didefinisikan sebagai seluruh usaha yang dibawa pekerja untuk diinvestasikan ke dalam perusahaan. investasi yang dimaksud adalah dalam bentuk pengelolaan pekerjaan yang akan menghasilkan kinerja bisnis. Dalam bekerja manusia akan menggunakan pengetahuan, keterampilan, dan kemampuan yang dimiliki untuk berinovasi, dan berkembang dalam organisasi.

Perbedaan keduanya terletak pada spesifiasnya. Industry Specific Human Capital kurang memiliki spesifitas perusahaan, sehingga seorang professional dapat pindah dari satu perusahaan ke perusahaan lainnya diseluruh pasar (dalam industry yang sama) tanpa menghilangkan nilai industry specific perusahaan sebelumnya. Lebih lanjut (Ramanda \& Muchtar, 2017) Human Capital mencerminkan kemampuan kolektif perusahaan untuk menghasilkan solusi terbaik berdasarkan pengetahuan yang dimiliki oleh orang-orang yang ada dalam perusahaan tersebut, dimana akan meningkat jika perusahaan mampu menggunakan pengetahuan yang dimiliki oleh karyawannya. 


\section{Structural Capital}

Marti dalam (Wirawan, 2017) menjelaskan bahwa Struktural Kapital adalah kemampuan perusahaan memanfaatkan intelektualitas dan keinovasian manusia (Sumber Daya Manusia) menciptakan kekayaan yang diaktualisasikan sebagai nilai dari prosedur, teknologi, rutinitas dan system yang berada di dalam perusahaan, dan juga merupakan cara-cara dimana komponen-komponen di dalam perusahaan disistematis, diinternalisir, dan diproses. Selanjutnya Bontis Nick (Ermawati et al., 2018) Struktural Capital merupakan kemampuan suatu organisasi atau perusahaan dalam memenuhi proses rutinitas perusahaan dan strukturnya yang mendukung usaha karyawan untuk menghasilkan kinerja intelektual yang optimal serta kinerja bisnis secara keseluruhan, misalnya system operasional perusahaan, budaya organisasi dan filosofi. Termasuk dalam hal ini adalah data base, organizatioinal charts, process manuals, strategies, routines dan segala hal yang membuat nilai perusahaan lebih besar dari nilai materialnya. Disisi lain Daneshi dalam (Eliana, 2017) Structural Capital merupakan hardware, software, data base, struktur organisasi, hak paten, nama baik perusahaan dan hal lainnya yang digunakan tenaga kerja perusahaan untuk mendukung proses dann aktifitas bisnis peusahaan. Hasil structural capital lebih ditekankan pada pengetahuan yang melekat pada tenaga kerja perusahaan dengan menjalankan rutinitas organisasi, Bonti (Eliana, 2017).

\section{Customer Capital}

Edvinsson dalam (Sukarno \& Nirawati, 2016) Customer Capital merupakan hubungan baik antara perusahaan dengan customer atau relasi sehingga mendukung perkembangan bisnis perusahaan tersebut. Selanjutnya Strattovic \& Mar (Pritiza, 2007) konsep penting dari Customer Capital adalah pengetahuan yang dibentuk dalam marketing channels, hubungan yang baik antara perusahaan dengan customer sehingga mendukung perkembangan bisnis. Contoh Customer Capital adalah image, loyalitas konsumen, kepuasan konsumen, hubungan dengan supplier, kekuatan komersial, kapasitas negoisasi dengan entitas keuangan dan lingkungan aktivitas. (Eliana, 2017) Customer Capital merupakan asset yang tampak dari reputasi perusahaan dan loyalitas konsumen. Customer capital didefinisikan sebagai sumber daya yang berkaitan dengan konsumen. 
Customer capital merupakan hubungan yang dibangun dengan konsumen dan bagian lain yang signifikan dari struktur kapita. Customer capital merupakan hubungan harmonis yang dimiliki oleh peusahaan dengan para mitranya, baik yang berasal dari para pemasok yang dapat diandalkan dan berkualitas. Customer capital juga timbul dari konsumen yang loyal dan merasa puas akan pelayanan yang telah diberikan yang akan membuat meereka tetap kembali kepada perusahaan yang bersangkutan.

Social Capital

Coleman (Syamni \& Malikussaleh, 2010) mendefinisikan bahwa Social Capital sebagai semua aspek yang mengarah dan diciptakan untuk memudahkan tindkan individu dalam struktur social. Struktur social melahirkan dorongan social menjadi lebih bekuasa atas perilaku individu. Dorongan social tersebut yang disesuaikan dengan norma-norma social meliputi kultur yang dominan, pengaruh kekuatan social lain atas perilaku lebih umum. Putnam (Handoyo, 2014) mendefinisikan modal social sebagai bagian dari organisasi social, seperti kepercayaan, norma dan jaringan yang dapat meningkatkan efesiensi masyarakat dengan memfasilitasi tindakantindakan terkoordinasi.

Nilai Organisasi

Menurut (Hapsari, 2015) nilai organisasi merupakan tuntunan atau pedoman yang mendasari bagaimana seseorang atau sebuah organisasi berfikir, mengambil keputusan, bersikap dan bertindak, nilai-nilai juga bisa diartikan gambaran dialog yang selalu terjadi dalam diri kita, yang menentukan apa yang penting dana pa yang tidak, apa yang boleh dan apa yang tidak.

\section{Metode Pemecahan Masalah}

1) Penguatan Human Capital dalam meningkatkan Organization Value UMKM

Modal manusia mencerminkan kompetensi seseorang dalam bekerja. Hal tersebut berarti bahwa human capital merupakan factor penting yang ada dalam organisasi karena dapat memberikan sumbangan besar bagi perkembangan dan kemajuan organisasi. Burud \& Tumolo dalam 
(Prasojo, 2017) pengelolaan human capital dan penerapan strategis memiliki manfaat setidaknya memuat hal-hal sebagai berikut :

1) Kekuatan kerja sebagai realitas baru, diyakini bahwa tujuan organisasi bukan semata-mata mencari keuntungan melainkan komitmen saling terbuka dalam suatu lingkungan kerja, sehingga mendorong adanya rasa tanggung jawab terhadap pekerjaan.

2) Factor manusia menentukan keberhasilan tujuan organisasi, melalui penerapan intellectual capital (talent, knowledge, dan skill) dan relationship capital (hubungan dengan customer, stakeholders).

3) Manusia adalah unsur yang terpenting untuk mencari keunggulan kompetitif melalui kreativitas dan pengetahuan yang mereka miliki, hubungan mereka dengan customer, rekan kerja, dan professional network.

4) Kekuatan strategi adaptif dalam mengungkit human capital, terletak pada metode praktis beradaptasi yang mencakup :

- Strategi berinvestasi melalui orang

- Strategi mengadopsi keyakinan baru

- Strategi memahami budaya organisasi

- Stragi mentransformasi praktik manajemen

- Strategi memastikan kesesuaian antara keyakinan, budaya, dan praktik.

Human capital merupakan sesuatu yang penting bagi kemajuan organisasi, karena dapat mempengaruhi produktivitas, hal yang harus diperhatikan untuk meningkatkan human capital dalam suatu organisasi:

- Merancang proses perencanaan strategi untuk memenuhi kebutuhan organisasi

Merancang perencanaan strategi organisasi adalah mengenal, mengubah, memodifikaasi, atau mengembangkan struktur organisasi, struktur, dan/atau konfigurasi tim agar sesuai dengan strategi dan meningkatkan kinerja organisasi. Hal tersebut bertujuan untuk mengetahui mengenai struktur organisasi mana yang paling sesuai dengan kebutuhan organisasi yang sedang dijalani.

- Implement the strategic paln 
Rencana stragtegi tidak banyak berguna bagi sebuah organisasi tanpa adanya saranan untuk mewujudkannya dan implementasi merupakan bagian penting dari proses perencanaan strategi. Organisasi yang telah menyusun perencanaan strategi perlu adanya proses untuk menerapkan rencana tersebut. Proses implementasi dapat bervariasi dari suatu organisasi ke organisasi yang lain, namum organisasi dapat memastikan bahwa pelaksanaannya berhasil dan rencana strategisnya dapat berjalan secara efektif.

- Evaluate and Monitor the strategic plan

Evaluate and Monitor the strategic plan merupakan langkah terakhir dalam rangkaian proses perencanaan strategi. Rencana tersebut harus mencakup evaluasi diri dan evaluasi independen, hasilnya sangat diperlukan untuk memperbaiki dan menyesuaikan rencana awal. Sebenarnya evaluate and monitor the strategis plan adalah untuk menciptakan lingkungan tepat untuk berbagai pengalaman, menyebarkan dan mendiskusikan kemajuan, hasil dan isu dan memberikan saran pada fase pelaksanaan perencanaan yang relevan, kondusif untuk pembelajaran dan peningkatan secara keseluruhan dalam perencanaan organisasi.

Untuk mengelola human capital dalam organisasi diperlukan pengetahuan tentang perilaku humani dan dan kemampuan untuk mengelolanya agar penyusunan human dalam organisasi relevan dengan strateginya, Sehingga seseorang yang berada dalam organisasi betul-betul sesuai dengan kualifikasi yang ditetapkan. Ssetiap organisasi akan selalu memiliki tantangan tentang bagaimana mengelola bakat yang dimiliki oleh pegawaianya secara efektif. Tentunya ini memerlukuan kesiapan organisasi dalam mengelola segala sumber daya dalam mengembangkan, menyelaraskan dengan cara mendukung modal strategis organisasi dan kebutuhan organisasi.

Hal yang harus diperhatikan dalam meningkatkan human capital pada organisasi (Prasojo, 2017) :

1. Desain Program Strategi Manajemen Human Capital

Human capital yang dipersiapkan oleh organisasi harus disesuaikan dengan strategi dan lingkungannya. Agar human capital yang dimiliki 
oleh organisasi berkualitas dibutuhkan adanya perencanaan yang matang dari seorang pimpinan, sehingga pengembangan terhadap pegawai dapat dilakukan secara efektif dan efisien.

2. Akuisisi Bakat Pegawai

Tidak bisa dipungkiri bahwa human resources dalam sebuah organisasi merupakan salah satu asset terpenting yang dimiliki oleh organisasi untuk mencapai tujuan, terdapat lima elemen system manajemen human capital yang relative kuat dalam akuisis bakat pegawai :

- Staffing

Upaya yang dilakukan oleh organisasi untuk memperoleh orang yang terbaik dalam organisasi dengan mengembangkan keterampilan dan kemampuannya.

- Planning

(Sunarta, 2010) menjelaskan bahwa inti dari perencanaan Sumber Daya Manusia adalah tersedianya data yang akurat tentang kebutuhan sumber daya manusia dalam kurun waktu tertentu secara kualitas maupun kuantitas.

- Recruitment

Keberhasilan dalam recruitmen pegawai menjadi starting point menuju organisasi yang memiliki kinerja yang berkualitas. Untuk mendapatkan pegawai yang sesuai dengan jabatan yang dipelukan. (Iskarim, 2017)

- Selection

Menurut (Rani, 2018) tujuan dari proses seleksi sendiri tidak lain untuk pencapaian visi dan misi dari organisasi, sehingga dari proses tersebut dapat mengetahui kemampuan dan karakteristik para pekerja yang baru direkrut.

- Placement

Menurut Soedjadi (Yuliana, 2015) Penempatan kerja merupakan suatu proses kegiatan yang dilakukan untuk menetukan seseorang pada posisi yang sesuai dengan formasi yang dibutuhkan, yang harus diperhatikan dalam penempatan kerja ini harus didasarkan 
kemampuan, keterampilan dan keahlian pegawai yang bersangkutan.

- Development

(Prasojo, 2017) menjelaskan bahwa efektivitas organisasi tergantung secara langsung pada efektivitas kerja SDM dari organisasi bersangkutan, meningkatkan efektivitas kerja baik pegawai lama maupun pegawai baru merupakan program penting yang harus dipersiapkan oleh suatu organisasi agar tetap kompeten.

- Performance Asseement

Merupakan penilaian kinerja terhadap pegawai pada suatu organisasi. Tujuan dari penilaian ini adalah untuk menjadi dasar bahan evaluasi apa yang sudah dicapai dan apa yang akan dilakuan.

\section{Talent Retention (Retensi Bakat)}

Semakin banyak kesempatan yang diberikan kepada pegawai untuk mengembangkan diri semakin baik buat organisasi, hal ini menunjukan ada perhatian karena semakin diperhatikan kesejahteraan pegawai akan semakin membuat mereka loyal kepada organisasi.

4. Pembentukan human capital

Pembentukan human capital ini dapat dilakukan melalui pengembangan diri pegawai dengan cara memberikan pendidikan dan pelatihan. Pendidikan terhadap pegawai merupakan hal yang paling penting dilalkukan oleh organisasi, di era sekarang ini organisasiorganisasi modern menganggap bahwa sumber daya manusia sebagai salah satu asset yang penting yang dapat menentukan kesuksesan

2) Penguatan Structure Capital dalam meningkatkan Organization Value UMKM

Modal Sumber daya manusia (human capital) tanpa didukung oleh sumber daya yang lain akan sia-sia, Oleh karena itu butuh adanya dukungan dari sumber daya-sumber daya lainnya, sumber daya tersebut adalah Structure Capital (modal structural). Menurut Bontis dalam (Ermawati et al., 2018) Struktur capital merupakan kemampuan suatu organisasi atau perusahaan dalam memenuhi proses rutinitas perusahaan dan strukturnya yang mendukung usaha karyawan untuk menghasilkan 
kinerja intelektual yang optimal serta kinerja bisnis secara keseluruhan. Lebih lanjut Preffer dalam (Wirawan, 2017) bahwa struktur capital memiliki dua tujuan yang harus dicapai, pertama mengkodifikasi pengetahuan yang dapat ditransfer, hal ini dilakukan agar sistemnya tidak hilang. Kedua, menghubungkan para karyawan dengan data, ahli dan keahlian.

Kim dan Mouborgne dalam (Anatan, 2000) modal struktur perlu didesain untuk memaksimalkan output intelektual dan hubungan penting yang memungkinkan modal intelektual untuk diukur dalam tingkatan organisasional. Menciptakan pengetahuan merupakan aktivitas intangible yang tidak dapat dipaksakan dan diawasi, dan hanya dapat terjadi ketika individu bekerja sama secara sukarela. Yang dapat dilakukan oleh organisasi adalah dengan memberikan pembelajaran tentang budaya, infrastruktur, dan insentif yang tepat untuk menghasilkan dan menyebarkan pengetahuan. Oleh karena itu modal structural merupakan infrastruktur yang dapat membantu mendukung pekerja untuk mengoptimumkan kinerja intelektualnya dan kinerja perusahaan secara keseluruhan.

3) Penguatan Customer Capital dalam meningkatkan Organization Value UMKM

Customer Capital merupakan hubungan yang harmonis yang dimiliki oleh perusahaan dengan para mitranya, baik yang berasal dari para pemasok yang andal dan bekualitas, berasal dari pelanggan yang loyal dan merasa puas akan pelayanan perusahaan bersangkutan, berasal dari hubungan perusahaan dengan pemerintah maupun dengan masyarakat sekitar, Prabowo dalam (Martin, 2017). Semakin baik hubungan nya, semakin besar peluang perusahaan belajar dengan pelanggan dan pemasoknya. Lebih lanjut Strattovic \& Mar dalam (Pritiza, 2007) menjelaskan bahwa konsep penting dari customer capital adalah pengetahuan yang baik antara perusahaan dengan customer sehingga mendukung perkembangna bisnis.

Kohli dan Joworski dalam (Divianto, 2010) mendefinisikannya sebagai generasi besar organisasi dari kecerdasan pasar yang berkaitandengan kebutuhan saat ini dan masa datang dari konsumen. 
Sehingga diseminasi kecerdasan ini harus dilaksanakan secara horizontal dan vertical dalam organisasi sehingga kompetensi dalam aktivitas organisasi atau respon terhadap perubahan pasar dapat dikembangkan. Jika sebuah organisasi menjadi focus terhadap konsumen dan menjadi penentu pasar, maka organisasi tersebut akan menciptakan rutinitas dan proses organisasi yang efisien serta dapat melayani konsumen denagan baik.

4) Penguatan Sosial Capital dalam meningkatkan Organization Value UMKM

Pemahaman tentang Sosial Capital ini diharapkan akan meningkatkan kinerja suatu organisasi, dari sisi bisnis melalui Sosial Capital akan membangun dan mendorong karyawan lebih menarik berbisnis, dan dapat mengeksplorasi kesempatan dan kemungkinan terbaik didapatkan dari jaringan kerja melalui Sosial Capital. Seperti yang diungkiapkan oleh Coleman dalam (Syamni \& Malikussaleh, 2010) bahwa Sosial Capital sebagai semua aspek yang mengarah dan diciptakan untuk memudahkan tindakan individu dalam struktur social. Struktur social melahirkan dorongan social menjadi lebih berkuasa atas perilaku individu. Dorong social tersebut yang disesuaikan dengan norma-norma social meliputi; kultur yang dominan, pengaruh kekuatan social lain-lain atas perilaku lebih umum.

Menurut Schwarz et al (Ciptosari et al., 2019) bahwa modal social bepotensi menjadi strategi dan sarana untuk mengembangkan organisasi termasuk UMKM.

\section{Kesimpulan}

Intelektual Kapital memberikan nilai lebih bagi perusahaan sehingga dapt meningkatkan daya saing organisasi perusahaan (UMKM).

Pemahaman terhadap asset intangible ini harus diperkuat dalam mind set pelaku UMKM, paradigma lama harus dirubah yang menganggap bahwa asset fisik berupa tanah, mesin dan tenaga kerja merupakan factor terpenting keberhasilan organisasi bisnis. Kini mereka juga harus menyadari bahwa ada asset penting lainnya yang tidak terlihat yang mempengaruhi keberhasilan usaha, asset tersebut berupa pengetahuan dan kompetensi karyawan, hubungan dengan pelanggan, inovasi, system 
computer dan administrasi, kreativitas serta kemampuan menguasai teknologi.

Human Capital, Structural Capital, Customer Capital, dan Social Capital merupakan komponen dalam Intelektual capital, keempat komponen tersebut merupakan asset berharga yang harus dimiliki oleh suatu organisasi agar dapat memberikan niali tambah yang dapat memberikan keuntungan yang efektif dan efesien. Pembentukan human capital ini dapat dilakukan melalui pengembangan diri pegawai dengan cara memberikan pendidikan dan pelatihan. Pembelajaran tentang budaya, infrastruktur, dan insentif yang tepat untuk menghasilkan dan menyebarkan pengetahuan merupaka cara untuk menguatkan Struktur Capital. Memberikan service yang excellent merupakan upaya untuk mempertahankan pelanggan. Bonding Social Capital, Bridging Social Capital, Linking Social Capital merupakan modal social yang dapat memberikan pemahaman konseptual bahwa modal social yang terbentuk dapat menciptakan hasil yang berbeda.

\section{Daftar Pustaka}

Anatan, L. (2000). MANAJEMEN MODAL INTELEKTUAL : STRATEGI MEMAKSIMALKAN NILAI MODAL INTELEKTUAL DALAM TECHNOLOGY DRIVEN. 1-10.

Astuti, Y. (2015). Modal Intelektual Dalam Pengembangan Ekonomi Kreatif: Studi Kasus Pada Sentra Kerajinan Sepatu. 103-114.

Ciptosari, F., Prabawa, T. S., \& Bele, A. (2019). Social Capital Dalam

Kewirausahaan Lokal, Kajian Keterlibatan Masyarakat Dalam

Pariwisata Di Delha, Kab. Rote Ndao, Nusa Tenggara Timur. Jurnal

Kawistara, 9(1), 45. https://doi.org/10.22146/kawistara.37992

Cyntya\&Setiawan. (2013). MODAL INTELEKTUAL DAN DAMPAKNYA BAGAI KEBERHASILAN ORGANISASI. 1-15.

Divianto. (2010). Pengaruh Faktor-Faktor Intellectual Capital (Human

Capital, Structural Capital dan Customer Capital) Terhadap Business

Performance. Jurnal Ilmiah Orasi Bisnis, Vol 4, pp 81-99.

Dzulfikri, A., \& Kusworo, B. (2019). Sikap, Motivasi, dan Minat

Berwirausaha Mahasiswa di Surabaya. JKMP (Jurnal Kebijakan Dan 
Manajemen Publik), 5(2), 183.

https://doi.org/10.21070/jkmp.v5i2.1310

Eliana, S. (2017). Pengaruh IIntellectual Capital (Human Capital, Structure Capital dan Customer Capital) Terhadap Kinerja Perusahaan

Manufaktur yang Terdapat di BEI. 1(2013), 3-5.

Endri. (2010). Peran Human Capital Dalam Meningkatkan Kinerja

Perusahaan: Suatu Tinjauan Teoritis Dan Empiris. Jurnal Administrasi

Bisnis, 6(2), 179-190.

Ermawati, Y., Noch, M. Y., \& Zakaria. (2018). Analisis Human Capital Dan

Structural Capital Dalam Meningkatkan Kinerja Keuangan dan Harga

Saham Perusahaan Perbankan. Future Jurnal Manajemen Dan Akuntansi, 6(1), 47-59.

Hafni, R., \& Rozali, A. (2017). Analisis Usaha Mikro, Kecil, dan Menengah (umkm) terhadap Penyerapan Tenaga Kerja di Indonesia. Ilmu Ekonomi Dan Studin Pembangunan, 15(2), 77-96.

http://jurnal.umsu.ac.id/index.php/ekawan/article/view/1034/pdf_58 Handoyo, E. (2014). Kontribusi Modal Sosial Dalam Meningkatkan

Kesejahteraan Pedagang Kaki Lima Pascarelokasi. Komunitas:

International Journal of Indonesian Society and Culture, 5(2), 252-

266. https://doi.org/10.15294/komunitas.v5i2.2743

Hapsari, S. Y. (2015). PENGARUH KEPUASAN KERJA, MOTIVASI,

NILAI ORGANISASI TERHADAP ORGANIZATIONAL

CITIZESHIP BEHAVIOR (OCB) ( Studi kasus pada RS. Telogorejo semarang). Manajemen SDM Universitas Pandanaran Semarang.

Hartati, N. (2015). Intellectual Capital Dalam Meningkatkan Daya Saing:

Sebuah Telaah Literatur. Etikonomi, 13(1), 51-68.

https://doi.org/10.15408/etk.v13i1.1878

Iskarim, M. (2017). Rekrutmen Pegawai Menuju Kinerja Organisasi yang Berkualitas dalam Perspektif MSDM dan Islam. 2(November), 307327.

Martin. (2017). Pengaruh Human Capital, Structural Capital, Customer

Capital Dan Good Corporate Governance Terhadap Profitabilitas

Perusahaan (Studi Empiris Pada Perusahaan Perbankan Yang Terdaftar

Di Bursa Efek Indonesia Pada Tahun 2012-2015). JIMAT (Jurnal 
Ilmiah Mahasiswa Akuntansi S1), 7(1).

https://doi.org/10.23887/jimat.v7i1.9471

Narimawati, U. (2011). Peranan Modal Intelektual Dosen dalam

Menciptakan Kualitas Lulusan. Majalah Ilmiah UNIKOM, 6(2), 143 156.

Prasojo, D. (2017). Manajemen Strtegi Human Capital dalam Pendidikan. Pritiza. (2007). Pengaruh Human capital Terhadap Business Performance

Melaului Customer Capital. Human Capital, 4(2), 1-206.

https://doi.org/10.1017/UPO9788175968400

Ramanda, Y., \& Muchtar, B. (2017). PENGARUH HUMAN CAPITAL,

RELATIONAL CAPITAL DAN ORGANIZATIONAL CAPITAL

TERHADAP KINERJA PEGAWAI (Studi pada Badan Ketahanan

Pangan Provinsi Sumatera Barat).

Rani, D. P. (2018). Analisa Proses Pelaksanaan Rekrutmen, Seleksi, dan

Penempatan Kerja Karyawan (Studi pada Hotel dan Restoran

Mahkota Plengkung Banyuwangi). 58(2).

Salsabila. (2019). Pengaruh Human Capital, Customer Capital dan

Technological Capital Terhadap Kinerja Bisnis ( Studi Kasus pada

UMKM Kuliner di Jalan Setia Budi Medan ).

Santoso, S. (2011). Pengaruh Modal Intelektual dan Pengungkapannya

Terhadap Kinerja Perusahaan. Jurnal Akuntansi Dan Keuangan, 14(1).

https://doi.org/10.9744/jak.14.1.16-31

Saragih, R. (2017). Membangun USAha Kreatif, Inovatif dan Bermanfaat

melalui Penerapan Kewirausahaan Sosial. Jurnal Kewirausahaan, 3(2), 26-34.

Suharyono. (2014). Sikap Dan Perilaku Wirausahawan. Jurnal Ekonomi MODERNISASI, 10(1), 38. https://doi.org/10.21067/jem.v10i1.774

Sukarno, G., \& Nirawati, L. (2016). KONTRIBUSI HUMAN CAPITAL dan CUSTOMER CAPITAL DALAM MENGGAPAI KINERJA CAFÉ dan RESTO di SURABAYA. Jurnal Ilmu Sosial, 15(2), 137. https://doi.org/10.14710/jis.15.2.2016.137-149

Sunarta. (2010). perncanaan Sumber Daya Manusi (Kunci Keberhasilah Organisasi). FISE Universitas Negeri Yogyakarta, XXXVI.

Syamni, G., \& Malikussaleh, U. (2010). Profil Social Capital Suatu Kajian 
Literatur. Jurnal Bisnis Dan Ekonomi (JBE), 17(2), 174-182.

Tohani, E. (2014). Pemanfaatan modal sosial (Social Capital) Dalam

Program Pendidikan Desa Vokasi di Gemawang Kabupaten Semarang.

Jurnal Penelitian Ilmu Pendidikan, 7.

Undang no 20 Tahun 2008 tentang Usaha Mikro Kecil dan Menengah, (2008).

Widiastuti, E., \& Sulistyandari. (2013). Peningkatan daya saing ukm melalui peran modal intelektual dan kinerja keuangan. Proceeding Seminar Nasional \& Call For Papers (SCA-3), Vol.3 No.1.

Wirawan, S. (2017). Pengaruh human capital, structural capital, dan customer capital terhadap kinerja perusahaan pada perusahaan daerah air minum (pdam) di kabupaten tabalong. 1(2).

Yuliana. (2015). Penempatan Pegawai Dalam Meningkatkan Kinerja Di Lingkungan Kerja Badan Pengelolaan Keuangan Dan Aset Daerah Kota Samarinda Isra Yuliana 1, Djumadi 2 , DB. Paranoan 3. 3(4), 428-440.

Zuliyati, Z., \& Delima, Z. M. (2017). Intellectual Capital dan Kinerja UMKM. Seminar Nasional Dan Call for Paper 2017 Strategi Pengembangan Sumber Daya Manusia Melalui Publikasi Jurnal Ilmiah Dalam Menyikapi Permenristekdikti No.20 Tahun 2017, 20, 280-290. 